\title{
MisCONSTRUING WHISTLEBLOWER IMMUNITY UNDER THE DEFEND TRADE SECRETS ACT
}

\begin{abstract}
Peter S. Menell*
In crafting the Defend Trade Secrets Act of 2016 (DTSA), Congress went beyond the federalization of state trade secret protection to tackle a broader social justice problem: the misuse of nondisclosure agreements (NDAs) to discourage reporting of illegal activity in a variety of areas. The past few decades have witnessed devastating government contracting abuses, regulatory violations, and deceptive financial schemes that have hurt the public and cost taxpayers and investors billions of dollars. Congress recognized that immunizing whistleblowers from the cost and risk of trade secret lability for providing information to the Government could spur law enforcement. But could this goal be accomplished without jeopardizing legitimate trade secret protection?
\end{abstract}

\section{The IMMUNiTy SOLUTION}

Congress solved the problem through a true "cone of silence." Congress immunized whistleblowers from liability under federal and state trade secret law for disclosure, in confidence, of trade secrets to government officials and attorneys for the purpose of reporting or investigating a suspected violation of law. Defend Trade Secrets Act of 2016, $\$ 7$ (codified at 18 U.S.C. $\S 1833$ (B)(1)(A) (2012)). By limiting disclosure to trusted intermediariesgovernment officials bound by state and federal law to protect trade secrets and attorneys bound by confidentiality obligations - the DTSA whistleblower immunity regime promotes law enforcement without risking commercial harm to legitimate trade secret owners.

Congress recognized that whistleblowers face dire risks of retaliation and costly legal expenses by even consulting with an attorney about allegedly illegal activity by their employer. Hence, merely affording whistleblowers a defense to liability for seeking to provide information about alleged misconduct

* Koret Professor of Law and Director, Berkeley Center for Law \& Technology, University of California, Berkeley, School of Law. An earlier draft of Professor S. Menell, Tailoring a Public Policy Exception to Trade Secret Protection, 105 CAL. L. REV. (forthcoming 2017), attracted the attention of congressional staff members working on the Defend Trade Secrets Act of 2016. Section 7 of that legislation ("Immunity from Liability for Confidential Disclosure of a Trade Secret to the Government or in a Court Filing") implements the proposals set forth in that article. 
would do little to promote law enforcement. The mere risk of having to defend trade secret litigation, with its attendant legal costs and career repercussions, would discourage whistleblowers from coming forward or seeking legal counsel. Instead, Congress chose to insulate whistleblowers from exposure to trade secret liability through an express grant of immunity.

As Senate Judiciary Committee Chairman Charles Grassley, a co-sponsor of the whistleblower immunity provision, explained, "Too often, individuals who come forward to report wrongdoing in the workplace are punished for simply telling the truth. The amendment I championed with Senator Leahy ensures that these whistleblowers won't be slapped with allegations of trade secret theft when responsibly exposing misconduct. It's another way we can prevent retaliation and even encourage people to speak out when they witness violations of the law."1

Senator Leahy added that "Whistleblowers serve an essential role in ensuring accountability. It is important that whistleblowers have strong and effective avenues to come forward without fear of intimidation or retaliation. The amendment I authored with Senator Grassley takes another important step in our bipartisan efforts to protect whistleblowers and promote accountability." 2

In immunizing whistleblowers from trade secret liability, Congress recognized that whistleblowers serve as quasi-public actors -- private attorneys general. Under the False Claims Act, for example, the whistleblowing "relator" acts in the name of the government. The relator's counsel works in conjunction with government enforcers. The government obtains the recovery and rewards the relator a share for his or her assistance. In other types of whistleblower programs, such as the Dodd-Frank Wall Street Reform and Consumer Protection Act's SEC and CFTC regimes, the whistleblower provides information in confidence to the government and receives a reward if the government is successful in recovering funds.

By its essential nature, immunity extinguishes liability before litigation gets underway, just as a vaccine immunizes the patient against disease, and thus differs from a "defense" to liability. As Justice Anthony Kennedy explained in Saucier v. Katz, 533 U.S. 194 (2001), a case applying qualified-immunity to a claim that a Secret Service agent had used excessive force in removing a protester, immunity is not a "mere defense" to liability but an "immunity from suit." The Court stressed that immunity issues must be resolved as early as possible based on the public policies animating the grant of immunity. In the context of qualified immunity, for example, the "concern of the immunity inquiry is to acknowledge that reasonable mistakes can be made as to the legal constraints on particular police conduct." Officers have difficulty in assessing the amount of force that is required in a particular circumstance. If their mistake as

${ }^{1}$ See Press Release, Office of Senator Chuck Grassley, Leahy-Grassley Amendment Protecting Whistleblowers Earns Unanimous Support in Judiciary Committee (Jan. 28, 2016), https:/www.grassley.senate.gov/news/news-releases/leahy-grassley-amendment-protectingwhistleblowers-earns-unanimous-support [https://perma.cc/J2L3-R56Q].

${ }^{2} I d$. (emphasis added). 
to "what the law requires is reasonable, however, the officer is entitled to the immunity defense." In the DTSA context, the purpose of the immunity was to eliminate the need for a whistleblower to undergo the expense and strain of defending a trade secret lawsuit.

The DTSA whistleblower immunity went into effect on May 11, 2016, the day the DTSA was signed into law. The first reported decision applying the whistleblower immunity provision issued on December $6,2016 .{ }^{3}$ Unfortunately, the court misconstrued the immunity provision, creating the very chilling effects that Congress mandated that the courts avoid.

\section{UNUM GROUP V. LOFTUS}

According to the court's background summary, Unum Group, a Fortune 500 insurance company, hired Timothy Loftus in 1985. Unum promoted Loftus to Director of Disability Insurance Benefits in 2004. In September 2016, Unum's in-house counsel interviewed Loftus as part of an internal investigation of claims practices. Later that week, Loftus removed several boxes of information and a laptop computer from the Unum offices after usual business hours. Unum requested that Loftus return these materials. Loftus refused to return the documents, although he did return the laptop. Through his counsel, Loftus informed Unum that the documents "may be evidence or otherwise have a material bearing on certain matters which are the subject of both historical and current governmental inquiries concerning the business practices of Unum" and that the documents had been secured to prevent their destruction "pending both internal and apparent external investigations of misconduct at Unum." On October 21, 2016, Loftus' counsel informed Unum's counsel that Loftus provided the documents to his counsel to obtain an "analysis of his legal position vis a vis his employer and the issue of his employer's compliance with the regulatory settlement agreement to which it was a party." Nonetheless, Unum sued Loftus for federal and state trade secret misappropriation as well as state law conversion.

This lawsuit presents a straightforward application of the whistleblower immunity provision, which provides in relevant part:

(1) Immunity. An individual shall not be held criminally or civilly liable under any Federal or State trade secret law for the disclosure of a trade secret that

(A) is made

(i) in confidence to a Federal, State, or local government official, either directly or indirectly, or to an attorney; and

(ii) solely for the purpose of reporting or investigating a suspected violation of law; or

\footnotetext{
${ }^{3}$ Unum Group v. Loftus, No. 4: 16-CV-40154-TSH, 2016 WL 7115967 (D. Mass. Dec. 6, 2016).
} 
(B) is made in a complaint or other document filed in a lawsuit or other proceeding, if such filing is made under seal. ${ }^{4}$

Not only is the section specifically identified as "Immunity," but the provision requires that employers notify employees of "the immunity set forth in this subsection." Therefore, Loftus' motion to dismiss the federal and state trade secret claims should have been granted. With dismissal of the trade secret claims, the state conversion claim loses its jurisdictional hook and likewise should have been dismissed. Furthermore, Loftus should have been awarded attorney's fees for having to defend a bad faith misappropriation claim. ${ }^{6}$

The court, however, misapprehended the DTSA whistleblower protection scheme. Rather than recognize that Loftus enjoyed immunity from liability, the court treated the whistleblower provision merely as an affirmative defense. The court declined to dismiss the trade secret misappropriation claim on the following basis:

While Loftus contends that he is entitled to immunity under the DTSA because he handed Unum's documents over to his attorney to pursue legal action against Unum for alleged unlawful activities, the record lacks facts to support or reject his affirmative defense at this stage of litigation. There has been no discovery to determine the significance of the documents taken or their contents, and Loftus has not filed any potential lawsuit that could be supported by information in those documents. Further, it is not ascertainable from the complaint whether Loftus turned over all of Unum's documents to his attorney, which documents he took and what information they contained, or whether he used, is using, or plans to use, those documents for any purpose other than investigating a potential violation of law. Taking all facts in the complaint as true, and making all reasonable inferences in favor of Unum, the court finds the complaint states a plausible claim for trade secret misappropriation and declines to dismiss [the trade secret misappropriation claims]. ${ }^{\text {? }}$

This is precisely the murky situation that Congress expressly corrected when it immunized employees and contractors. Notwithstanding that Unum provided no evidence that Loftus has done anything more than share company records with his counsel as part of an effort to investigate a suspected violation of law, the court nonetheless imposed upon Loftus the burden of proving that he did not have an improper purpose. In so doing, the court ignores the vaccine and subjects Loftus to the very disease that Congress cured: the imposition of substantial costs and adverse career repercussions by sharing, in confidence, company documents with counsel. Under the court's approach, any trade secret owner can require a whistleblower to defend a trade secret lawsuit merely by alleging that there is a dispute over the employee's motivation for providing trade secret documents to their attorney.

It was this very catch-22 that led Congress to immunize potential whistleblowers. Prior to passage of the DTSA, courts recognized a limited public poli-

${ }^{4} 18$ U.S.C. $\$ 1833$ (b) (2012).

${ }^{5} 18$ U.S.C. $\$ 1833(\mathrm{~b})(3)(\mathrm{A})$ (emphasis added).

${ }^{6}$ See 18 U.S.C. $\$ 1836(\mathrm{~b})(3)(\mathrm{D})$.

${ }^{7}$ Unum, $2016 \mathrm{WL} 7115967$, at *2. 
cy privilege to disclose trade secrets. ${ }^{8}$ But uncertainty about the existence, scope, and requirements of a public policy defense and imposing on lay whistleblowers, as some courts had, the requirement of demonstrating that they provided only "relevant" information was viewed as undermining the important public purpose of encouraging whistleblowers to come forward. The DTSA regime, which provides employees and contractors a clear, straightforward, and reasonable procedure for consulting counsel, serves the paramount public interest in promoting law enforcement and ferreting out corporate fraud while providing appropriate protection for legitimate trade secrets.

In concluding its opinion, the court notes that "no whistleblower suit has been filed. Unum does not know what Loftus took or what he is going to do with it. Loftus's self-help discovery and threat of potential action in the future are not mitigated by the existence of an actual lawsuit." Yet virtually all whistleblower cases begin this way. The False Claims Act, for example, authorizes a relator to submit material evidence and information to the government under seal and to file a complaint under seal and without providing it to the defendant while the government investigates the allegations. ${ }^{9}$ The purpose of the seal is to protect the government's investigation, ${ }^{10}$ which routinely (and ideally) occurs without notice to the defendant.

\section{TURNING IMMUNITY ON ITS HEAD}

The court's overbroad remedial order turns Congress' immunity regime on its head. The court's preliminary injunction orders Loftus and his counsel to turn over all Unum documents - whether in print or electronic form - to the court, destroy all copies of Unum documents, and to not make any copies of Unum documents. The court ordered Loftus to not deliver any Unum documents to any third party (presumably including the government) without the express permission of the court. The court further ordered Loftus and his counsel to file an affidavit setting forth whether Unum documents have been given to any third party, and, if so, the circumstances under which said documents were given.

The court's order also undermines the very investigatory and reporting activities specifically authorized by the DTSA, the False Claims Act, the DoddFrank Act, and various other whistleblower statutes and protections. These statutes have detailed provisions that allow the government and whistleblowers to investigate potential violations of law without the knowledge or interference of the target company. Yet, in misconstruing the DTSA's whistleblower im-

\footnotetext{
${ }^{8}$ See Restatement (ThiRd) OF UnFair COMPETITION $\$ 39 \mathrm{cmt}$ c c (AM. LAW InST. 1995) (noting that the exception "depends upon the circumstances of the particular case, including the nature of the information, the purpose of the disclosure, and the means by which the actor acquired the information"); Peter S. Menell, Tailoring a Public Policy Exception to Trade Secret Protection, 105 Cal. L. Rev. (forthcoming 2017).

${ }^{9} 31$ U.S.C. $\$ 3730(\mathrm{~b})(2)$ (2012).

${ }^{10}$ See State Farm Fire and Cas. Co. v. United States ex rel. Rigsby, 137 S.Ct. 436,443 (2016).
} 
munity regime, the court has effectively provided Unum with pre-investigation discovery of potential regulatory violations and has effectively commandeered such investigation.

\section{FAITHFUL, BALANCED IMPLEMENTATION OF WHISTLEBLOWER IMMUNITY}

In addressing the dilemma of encouraging law enforcement while protecting trade secrets, Congress granted employees and contractors immunity so long as they follow a clear and straightforward process. They may share company documents with their attorneys in confidence for the purpose of investigating allegedly illegal corporate activity or pursuing a retaliation claim. Employers may not pursue trade secret liability for such confidential disclosures. The purpose of the whistleblower immunity regime is clear: Trade secret law may not be used to hide allegedly illegal conduct or discourage investigation of such matters. By choosing immunity, Congress shifted the law and legal process from the employer's advantage to the employee's and the public's.

The court's sole role in a case such as Unum Group v. Loftus is to decide whether immunity applies, with due regard for the DTSA's protected activities and public purposes. Where, as here, the employee asserts under oath that he disclosed company documents to government officials or an attorney in confidence solely for the purpose of reporting or investigating a suspected violation of law, the DTSA whistleblower regime requires the employer-trade secret owner to come forward with concrete evidence that the employee or contractor has shared trade secret information outside of the protected categories or for an impermissible purpose. Absent such evidence, the employee-contractor remains free to work with counsel to investigate and report alleged violations of law and immune from suit for trade secret violations. 


\title{
A LEFT OF LIBERAL INTERPRETATION OF TRUMP'S “BIG” WIN PART ONE: NEOLIBERALISM
}

\author{
Duncan Kennedy*
}

\begin{abstract}
This will hopefully be the first of three short pieces about the election, dealing here with the role of neoliberalism, then with "political correctness," and lastly with resistance.
\end{abstract}

The question of interpreting Donald Trump's election, in liberal discourse, is mainly "how can he have won, given that he is racist and sexist?" The answer of many of my friends is that he won because his racism and sexism appealed to a shockingly large part of the electorate, confirming that "our whole society is sexist and racist." According to the liberal conception, this is particularly true of the non-college part of the electorate, which had more "traditional" (racist and sexist) values and less cognitive ability to figure out that he was going to screw them. If they were not racist and sexist, they would have rejected him outright, no matter how much they didn't like Hillary. I think class, race and sex were key to everything, but in a different way than in that account.

It's hard to argue with the more careful, liberal-Democratic account in which the answer to the question "why is he president?" is that the swing states just barely tipped to Trump in spite of Clinton's solid victory in the popular vote. Why did that happen? The outcomes in Pennsylvania, Michigan, Wisconsin, etc. were so close that many situational factors could have been enough to determine the outcome.

Race figures in this analysis not as a general characteristic of the electorate but as one factor among many. The suppression of black votes in swing states is one of the things that could have made the difference. Another is Trump's "dog whistle" to serious white supremacists, which probably helped turn out previous non-voter racists. But at the same time we can attribute it to Comey, or to taking the rust belt for granted, or to Russian hacking, or to "the treacherous liberal media," to Hillary's personal weakness as a candidate, or any number of others, maybe even Bernie. Or all of them together.

Then there is the "structural" factor: white, non-college voters are overrepresented in swing states compared to the country as a whole, giving their rational and irrational resentments an accidentally outsized importance in this particular race. Last, African-Americans voted overwhelmingly for Clin-

* Emeritus professor of law, Harvard Law School. 
ton, but in nothing like the numbers for Obama, and it is hard to see voter suppression as explaining the whole effect.

Which factor we choose to focus on is not about the "true" cause, but about what we think is important in terms of our larger agenda. My larger agenda is to understand the race/gender/class dynamics of the current situation in order to get a sense of what the future is likely to hold in terms of perils and possibilities. In big terms, I want to argue the election did not signal a major shift to the right of American political consciousness, but it did signal a rebellion (not a revolt), by many non-college-educated whites in red states, swing states, and red pockets in blue states; against both political parties.

According to The Upshot, "Mrs. Clinton won Mr. Obama's white working class supporters by a margin of only 78 percent to 18 percent." ${ }^{1}$ While racism and sexism were definitely major factors in the election and in American society in general, they do not come close to explaining how Trump won Obama's sure thing swing states, and 62 percent of white non-college women. ${ }^{2}$

The large shift in voting by non-college-educated whites was, at least in part, plausibly a protest against the long running, shared neoliberal policy agenda of Democrats and Republicans that has "devastated" (just as Trump said) their communities. It was also plausibly a protest by non-college educated whites with "traditional values" against the particular way of enforcing liberal values that is loosely and pejoratively called political correctness.

I don't think these rebellions are any more "the" cause of the outcome than Comey's last minute intervention, but I think they are more interesting and more important for understanding the possibilities of resistance than the more situational factors.

\section{No MAJOR SHIFT TO THE RIGHT}

The election did not see significant changes in the balance of voting power among different political tendencies. The overall pattern of voting was similar to what it has been for the last many elections, with the country divided between red, blue, and swing states. Elections in the U.S. are close. The swing states, including some that pollsters had thought blue, went for Trump but by such small margins that the swing was much smaller than Clinton's popular vote margin. ${ }^{3}$

That margin was possible in spite of an increased Republican vote in many red states because Hillary increased the Democratic vote in solid blue states,

\footnotetext{
${ }^{1}$ Nate Cohn, Turnout Wasn't the Driver of Clinton's Defeat, N.Y. TiMES (MAR. 28, 2017), https:/www.nytimes.com/2017/03/28/upshot/a-2016-review-turnout-wasnt-the-driver-ofclintons-defeat.html [https://perma.cc/GD6L-WHGU].

${ }^{2}$ Clare Malone, Clinton Couldn't Win Over White Women, FIVETHIRTyEIGHT (Nov. 9, 2016, 7:16 PM), https://fivethirtyeight.com/features/clinton-couldnt-win-over-white-women [https://perma.cc/8BDQ-CHQS].

${ }^{3}$ Tim Meko et al., How Trump Won the Presidency with Razor-Thin Margins in Swing States, WASH. POST (Nov. 11, 2016), https://www.washingtonpost.com/graphics/politics/20 16-election/swing-state-margins [https://perma.cc/QQM6-GFBK].
} 
especially California and New York. ${ }^{4}$ At the micro level, within all states, "purple" counties (split between red and blue) continued to disappear at a surprising rate. Today, 61 percent of voters vote in counties that went for one candidate or the other by 60 percent or more, compared to $39 \%$ in $1992 .{ }^{5}$ Moreover, "between 1992 and 2016, the share of voters living in extreme landslide counties quintupled from 4 percent to 21 percent." In other words, the main shift was the intensification both at the state level and at the county level of the geographical polarization of the electorate.

The Republicans now control all federal branches and completely or partially control many state governments in red states. But there are many more red than blue states, and the Democrats completely or partially control state government in the populous, rich, culturally-dominant East and West coastal states. American federalism involves what, to Europeans, looks like massive delegations of power to the states, limiting the practical ability of the central (Trumpist) government to impose policy downward. Nonetheless the shift in state power at the national level, as opposed to electoral support, may give the Republicans/Trumpists a chance to change the electoral balance for the future. And the shift in state power has already permitted them to inflict major sometimes irreparable harm on the vulnerable across the social spectrum.

\section{Rebellion of Non-College-Educated Whites AGainst "DEVASTATION"}

To my mind, the shift in voting by non-college whites is the most interesting development of this cycle because of what it says about race and gender politics in the U.S. now and in the future.

The first interesting piece of evidence was the 538 column on districts in swing states that flipped from Obama to Trump or from Romney to Clinton. ${ }^{7}$ The study claimed that the thing that explained the flips was educational level, not income, with non-college districts going toward Trump and collegeeducated ones going toward Hillary ${ }^{8}$. The number of such districts was not large; most districts everywhere voted Republican or Democratic as they had in previous elections. Flipping is rare.

\footnotetext{
${ }^{4}$ Compare 2016 Presidential Election Results, PoLITICo (Dec. 13, 2016, 1:57 PM), http:/www politico.com/2016-election/results/map/president [https://perma.cc/F7Y7-YQG P] with Presidential Election Results, NBC NEws (Apr. 3, 2017, 2:02 PM), http://elec tions.nbcnews.com/ns/politics/2012/all/president/\#.WOKOOhjMy8o [https://perma.cc/Z26 Y-Q7FS].

${ }^{5}$ David Wasserman, Purple America Has All But Disappeared, FiveThIRTYEIGHT (Mar. 8, 2017, 11:33 AM), https:/fivethirtyeight.com/features/purple-america-has-all-but-disappear ed [https://perma.ce/NY8R-4GK9].

${ }^{6} I d$.

7 Clare Malone, Clinton Couldn't Win Over White Women, FIVETHIRTYEIGHT (Nov. 9, 2016, 7:16 PM), https://fivethirtyeight.com/features/clinton-couldnt-win-over-white-women [https://perma.cc/HA48-TZAP].

${ }^{8} I d$.
} 
A further study suggested that there were indeed many voters who flipped. ${ }^{9}$ But to explain the change in the outcome in swing states, two more significant factors were: first, that many non-college white voters who had voted for Obama did not turn out for Clinton or voted for third party candidates and, second, that many non-college whites who had not voted in 2012 turned out to vote for Trump. ${ }^{10}$ Non-college voter participation stayed close to constant, but the balance of enthusiasm and apathy shifted-red intensity overwhelming blue abstention.

Why would non-college whites vote for Trump instead of for Hillary? One part of the answer might be that they were voting against Hillary for the same reason they voted against Bush and Kasich in the primary. In other words, not because Trump was a Republican, but because he was trashing the dominant policies of the Democratic-Republican, neoliberal consensus. From this point of view, a crucial moment was his question to Hillary: you've been here for 25 years and what have you accomplished?

My liberal, and especially feminist, friends thought this was a truly bizarre charge: Hillary is one of the most accomplished human beings on the planet, as they understand it. But I think the meaning was that, in spite of progressive rhetoric supposedly favoring the weak and marginalized, liberal Democrats led by Hillary, Bill, and Obama, whether in power or out, have not managed to stem large losses-social, economic, cultural-to the people whose votes Trump was after.

This is about the "devastation" claim Trump made in the inaugural address. ${ }^{11}$ The claim is obviously false if understood as "Hillary has accomplished nothing at all" or "America is devastated." The point is nothing has been accomplished for a specific subset of non-college-educated whites. It makes no difference that unemployment is down to four percent nationally. The claim is about something that has been happening in particular, distinct locales. That things are going better or even very well in other locales just makes it worse.

Red states and red areas in blue states have larger poor, white, non-college populations than blue states and blue areas in red states. ${ }^{12}$ They are concentrated in areas that are post-industrial (read rust belt), or areas with declining agri-

\footnotetext{
${ }^{9}$ Philip Bump, The Counties That Flipped Parties to Swing the 2016 Election, WASH. POST (Nov. 15, 2016), https://www.washingtonpost.com/news/the-fix/wp/2016/11/15/the-count ies-that-flipped-parties-to-swing-the-2016-election/?utm_term $=.956 \mathrm{a} 9 \mathrm{c} 17 \mathrm{e} 95 \mathrm{c} \quad[\mathrm{https}: / \mathrm{perm}$ a.cc/F2UR-MZUN].

${ }^{10}$ Konstantin Killibarda \& Dana Roithmeyer, The Myth of the Rust Belt Revolt, SLATE (Dec. 1, 2016, 3:59 PM), http:/www.slate.com/articles/news_and_politics/politics/2016/12/ the_myth_of_the_rust_belt_revolt.html [https://perma.cc/J8MZ-F3UM].

${ }^{11}$ Daniel Dale, Trump Casts Himself as America's Savior in Fiery Inaugural Address, THESTAR.COM (Jan. 20, 2017), https:/www.thestar.com/news/world/2017/01/20/donaldtrump-inauguration.html [https://perma.cc/R264-RSRA].

${ }^{12}$ Neil Irwin \& Josh Katz, The Geography of Trumpism, N.Y. Times: ThE UPSHOT (Mar. 12, 2016), https:/www.nytimes.com/2016/03/13/upshot/the-geography-of-trumpism.html [http $\mathrm{s}: / /$ perma.cc/35S2-YM8B].
} 
cultural employment. ${ }^{13}$ Those areas are losing population to the (relatively) new, rapidly developing, economically diversified, megacities on the coasts and in the sunbelt, in both red and blue states. ${ }^{14}$

In declining areas, there are fewer and fewer high-paying, blue-collar jobs (manufacturing, construction, transport, agriculture, etc.), and low-skilled farm labor is long gone. ${ }^{15}$ Wages for this group have been stagnant or have actually gone down over the last thirty years. Jobs for people (mainly women) who have some college are also scarce because the main expanding areas of well-paid, white-collar jobs (e.g. health, education, finance, insurance, real estate, government) are in the megacities. ${ }^{16}$

A declining population with a declining economic base sets up a classic pattern of center-periphery unstable equilibrium. Think of southern Italy in relation to northern Italy. The center lures away the money of prosperous people and the most ambitious and competent of the young, inducing a downward spiral in the periphery and fueling the ascent of the center. This dynamic, taking place in the world of "traditional values" about gender and sexuality, generates an accompanying process of "social decay."

No jobs for high school graduates means unstable unions, especially when women are staying in school longer and have better job prospects. Norms of early and life-long marriage, and of shotgun marriage instead of abortion, are changing surprisingly rapidly. Divorce is now much more prevalent in this group than among the blue-state college educated. ${ }^{17}$ More and more couples never marry. Single parenthood is becoming the norm rather than the exception.

No jobs for high school graduates sharply reduces the incentive to finish, or to study where it isn't required in order to stay in school. Dropping out or just very bad performance by the weakest students (mainly guys) further reduces the employability of the young since good jobs require more, not less, education. The opioid crisis is not some bizarre anomaly in a musical-comedy, happy Midwest, but a key aspect of an emerging culture of dysfunction.

${ }^{13}$ Agricultural Workers: Employment Outlook Handbook, BUREAU OF LABOR STATISTICS, https://www.bls.gov/ooh/farming-fishing-and-forestry/agricultural-workers.htm [https://perm a.cc/UPM6-STPC] (last visited Apr. 13, 2017).

${ }^{14}$ Population and Migration Overview, ECon. Research SERv., U.S. Dep'T OF Agric., https:/www.ers.usda.gov/topics/rural-economy-population/population-migration [https://perma.cc/B29P-TUVZ] (last visited Apr. 13, 2017).

${ }_{15}$ Justin Fox, Farewell to the Blue-Collar Elite, ForBes (Apr. 6, 2015), https:/www.bloom berg.com/view/articles/2015-04-06/factory-worker-wages-are-nothing-special-these-days [https://perma.cc/5SXJ-HXSN].

${ }^{16}$ Joel Koltkin, The U.S. Cities Creating the Most White-Collar Jobs, ForBEs (July 21, 2016), https://www forbes.com/sites/joelkotkin/2016/07/21/the-u-s-cities-creating-the-mostwhite-collar-jobs-2016/\#1bf0557f22be [https://perma.cc/LQ9V-SDJD].

${ }^{17}$ Divorce Rate in the U.S., NAT'L CTR. FOR FAMILY AND MARRIAGE RES., BOWLING GREEN STATE UNIV., https:/www.bgsu.edu/ncfmr/resources/data/family-profiles/anderson-divorcerate-us-geo-2015-fp-16-21.html [https://perma.cc/8LHN-G73Z] (last visited Apr. 3, 2017). 
The crucial books here are Robert Putnam, Our Kids, ${ }^{18}$ from the left, and Coming Apart, ${ }^{19}$ by Charles Murray (yes, him), from the right, surprisingly in agreement that there is a white, ex-working class increasingly isolated from what is happening to everyone else and trapped (that is the word) at the bottom. But even where it is just decline, rather than "devastation," they agree that the biggest change from the 1950s for non-college whites is the virtual disappearance of upward social mobility. A high school diploma was once an indicator of promise; now, without more it indicates "no prospects."

In short, for this group, even Trump's much mocked evocation of a golden American past is right on point. I think what has happened to this group is really bad. The victims certainly deserve part of the blame for their fate. A "traditional values" response to the crisis - say by banning sex education and abortion-seems wildly counterproductive; locating the problem in big government or affirmative action or immigration likewise.

But I don't think the white, ex-working class deserves what has happened to them, even if racist and sexist attitudes and utterances and practices are more common (o.k., much more) there than among their college-educated counterparts. I think it was logical-if not justifiable-for non-college, white voters in these particular deindustrialized or declining agricultural locales to vote for Trump.

He was equally contemptuous of Republicans and Democrats. Just maybe he intended to change whatever it was in the policies of both parties for the last few decades that had at least allowed, and maybe had actually produced, the "devastation" that they felt was obvious and undeniable.

\section{NeOliberal Policies Caused the Devastation}

Of course, phenomena like devastation are always causally overdetermined, just like the election outcome. And there is always the question of when we should regard an actor's mere "failure to act" as a cause of bad things happening when it is not certain whether action would have made a difference. We choose to focus on particular active or passive behavior as a cause for reasons of moral judgment and according to our own action agendas.

I think the single most important cause of devastation has been the adoption of "neoliberal" policies, equally by Democrats and Republicans, in and out of office, since approximately the Carter Administration. Nixon was the last president with a strong, affirmative model of state intervention to stabilize the system and inflect its growth. I certainly prefer the nicer Democratic neoliberal policies, but for the question of devastation I think they are equally to blame.

I don't think neoliberalism is a philosophy. I think of it as a set of policies that collectively eliminated particular regulatory structures that had produced relatively evenly distributed growth, leaving many other regulatory structures

${ }^{18}$ Robert Putnam, OUr Kids (2016).

19 Charles Murray, Coming Apart (2012). 
in place. Rather than a coherent vision of "the market," the drivers of policy change acted from a correct estimate that there would be many gainers, above all, and enormously the one percent for whom they acted. They had zero regard (or less!) for the many losers.

While it is common to begin the policy list with the global dimension, our devastation begins at home. Democrats and Republicans agree on a decentralized governmental structure that encourages states and municipalities to compete for private investment, and permits investors to move within and between states, without any responsibility for consequences left behind. This is the single most important legal/policy reason for decline of the peripheral area.

Democrats and Republicans agree on a labor law regime that has shrunk and disempowered organized labor, so that new developing areas can offer low wages and worker passivity in comparison with declining areas, and workers left behind have no legal power to slow or reverse the process. ${ }^{20}$

The deregulation of the financial system led to the concentration of economic power at the national level. ${ }^{21}$ The surviving giants-whether banks, manufacturing companies, agribusinesses, or Walmart and the national chain stores - used their power to eliminate smaller, less-mobile companies whose prosperity was tied to local conditions. ${ }^{22}$ This freed them to make their own location choices according to their national profit calculus regardless of local consequences. ${ }^{23}$ No more small-town downtown.

This set of policies might have set up the downward-spiraling centerperiphery dynamic even without globalization. The domestic economy is large and diverse enough for neoliberal policies to produce "global" dynamics right here at home. Already in the 1930 's, industry was beginning to flee the highwage, strong-union, blue cities of the Northeast for Georgia and North Carolina. ${ }^{24}$

During that same period, cheap cotton production in Egypt and India threatened the global competitiveness of the American textile industry, which depended on Southern cotton produced by cheap ex-slave labor. When the ruling planters and agribusinesses mechanized, they had enough power to throw about seven million black people off the land with no alternative to migration

${ }^{20}$ Julian Zelizer, How Labor Unions and Democrats Fell Out of Love, CNN (Aug. 31, 2014, 12:25 PM), http://www.cnn.com/2014/08/31/opinion/zelizer-labor-democrats [https://perm a.cc/Z8BK-DR94].

${ }^{21}$ Michel Chossudovsky, Global Financial Meltdown: Sweeping Deregulation of the U.S. Banking System, GLOB. RES. (Oct. 17, 2008), http:/www.globalresearch.ca/global-financialmeltdown-sweeping-deregulation-of-the-us-banking-system/10588 [https://perma.cc/9MX5G2CY].

22 Stacy Mitchell, The Impact of Chain Stores on Community, InST. FOR LOCAL SELFRELIANCE (Apr. 18, 2000), https://ilsr.org/impact-chain-stores-community [https://perma.cc/ 26VL-G65E].

${ }^{23}$ Contrast an earlier pro-small-business, antitrust philosophy and successful resistance in Japan.

${ }^{24}$ Daniel R. Fusfield \& Timothy Bates, The Political Economy of The URban Ghetto (1984). 
northward. But ... the industries that provided them unskilled jobs on arrival were just beginning to relocate from inner cities to the suburbs. The government subsidized this move in many ways, from mortgage credit to transport, and guaranteed its segregation. The poorer they got, the less the abandoned inner cities could compete for jobs with low tax white suburbs.

By the seventies, when the migration slowed, the new ghettos had their own spiral of economic deprivation combined with socio-cultural shock, with the same indicators as in today's non-college, white, marginalized areas. As with those areas today, the departure of African Americans with a chance in the post-civil rights, college-educated sector left the ghettos with "concentrated poverty." 25

The racial spiral occurred before neo-liberal policy thinking had become hegemonic. The progressive wing of the Democratic Party with some liberal Republican allies argued for policies that would have, albeit just mildly, countered the center-periphery dynamic. Richard Nixon's racist "southern strategy" successfully mobilized white fears against them. Left liberalism was over with Ted Kennedy's loss to Carter in the 1980 primary and Reagan's triumph.

At the same time, global neoliberal policies have certainly been a major factor in the devastation story. I think these are the ones that have counted the most:

The American red and blue elites collaboratively designed and implemented a liberalized world economy, reducing tariffs (and non-tariff barriers) and creating a world capital market. Countries with low labor costs compete for direct and indirect foreign investment by multinationals and banks. This is the basis of "outsourcing" from the US, eliminating jobs in declining areas. The global regime is a close parallel to the American federal system in which rising American states and municipalities offer American companies incentives for relocation from declining areas.

The liberalization of trade with China produced a massive shift of manufacturing out of the US into Chinese factories, which sell us all kinds of consumer goods at prices dramatically lower than before the shift.

Permission, by non-action, of the immigration of millions of low-skilled, relatively uneducated workers from Mexico, the Caribbean, and Central America, combined with technological change and massive government subsidies to agribusiness, weakened the small farm town economy but increased productivity and dramatically lowered food prices. (Unskilled immigrant labor also obviously competes with unskilled black labor left behind in poor urban neighborhoods, with liberals in denial.) Liberals sometimes speak as though support for immigration has been driven by human rights abuses, downplaying the dispossession of millions and millions of peasants by Latin American elites pursuing their own domestic neo-liberal policies.

${ }^{25}$ See generally William Julius Wilson, The Truly Disadvantaged (1987); William JULIUS WILSON, WHEN WORK DISAPPEARS (1996). 
In this account, neoliberal political and legal projects, both domestic and international, have reconfigured the U.S. economy into its present pattern of $\mathrm{red} / \mathrm{blue} /$ purple states and localities, and distributed non-college whites across that landscape.

The reconfiguration, along with technological change, was the vehicle of a dramatic, long-term rise both in GDP per capita and in household wealth. The losses to the internal periphery have been no more than a small fraction, in dollar terms, of the gains in dollars to the people living in the centers of development. Those people include migrants from the internal American periphery who escaped to a better life in the cities, and a large, post-civil-rights, black, middle class. Moreover, the gains to perhaps a billion very poor people living in the countries that now export to the US have been life-transforming.

\section{Blue ANd Red Elites Share Political/Moral Responsibility For DEVASTATION}

So what's the problem? The neoliberal policies caused the good development and they caused its bad effects. Because they are socio-cultural as well as economic, the bad effects go far beyond national trends of increased income and wealth inequality, wage stagnation, and differential red/blue state growth rates. They were concentrated on a subsector of non-college whites and the black, urban poor. The devastation has been a long-running story, first predicted, then documented, then predicted some more, then documented some more.

The bad effects were not a necessary cost of the gains. In other words, we could have had the gains of the transformation without the losses. The gains were so large that it would have been possible, without changing any neoliberal policy, to tax enough of them away from the gainers to fund large-scale attempts to halt or reverse peripheral downward spirals. Alternatively, it would have been possible to alter many neoliberal policies at the micro level, selectively departing from free trade and domestic uncompensated factor mobility (capital can't just up and leave), to tilt toward losers. Or some combination.

Nothing like that happened. This is obviously another over-determined dog that didn't bark. Maybe it wouldn't have worked anyway. Maybe American racism means there is no possible populist coalition of black and white outsiders, and maybe that is, in spite of what I've just argued, the true lesson of the election. It does seem that at some point on the road to Citizens United (no limits on campaign contributions to candidates and causes $)^{26}$, those who gained the most from the neoliberal transformation, namely the one percent, acquired a lock on both political parties.

According to Paul Krugman, because no one had proved that Hillary did a favor in exchange, it was outrageous to object to her millions of dollars in Wall Street speaking fees. To left outliers, it seems obvious why she didn't release the transcripts: she was pledging her faith in "the market" as neoliberal policy

${ }^{26}$ Citizens United v. Fed. Election Comm'n, 558 U.S. 310 (2010). 
for everyone, rich and poor alike, and against "redistribution" synonymous with "class warfare." If your issue was devastation, it was reasonable to see this as a more significant non-disclosure than Trump's sleazy tax return concealment.

Suppose that it's right that some interesting part of Trump's switching noncollege, white votes, and of Hillary's lost, no-show, white, non-college votes, were in rebellion against the Republican/Democrat, red/blue state consensus, from Bushes to Clintons. It seems clear already that nothing will come of it. The Inaugural was a farewell. These voters are obviously powerless in relation to the consensus. Only 40 percent of the electorate is white and non-college educated ${ }^{27}$ the putative rebels are a minority of the minority with no consensus about what's wrong or what to do about it. In terms of resources, the whole point is that the elites have reaped all the money and embedded institutional power from the transformation.

I don't think either party has a pragmatic reason to "learn from the rust belt revolt." Its success, if it was responsible for Trump, was an accident of the demographics of the electoral college. But Trump may have created a new opportunity. The big, rich, progressive blue states could tax back rich people's reductions at the federal level and innovate at home. Before looking at the implications of federalism for Trumpism, I turn now to the question of the "political correctness" issue in the election and its implications.

${ }^{27}$ David Wasserman, Mapping the 2016 Electorate: Demographics Don't Guarantee a Democratic White House, COOK POL. REP. (June 19, 2015), http://cookpolitical.com/story/86 08 [https://perma.cc/AX2D-LQUL]. 